\title{
Use of naloxone in valproate overdose
}

Sir,

I read with interest, the recent case presentation by Nasa et al. regarding the effectiveness of hemodialysis in a case of severe valproate overdose published in your journal. ${ }^{[1]}$

The authors stated that naloxone acted as a GABA antagonist. However, their patient did not show any improvement with naloxone. As you know, according to the textbook of Goldfrank's Toxicologic Emergencies, naloxone is not effective in valproic acidinduced central nervous system (CNS) or respiratory depression. ${ }^{[2]}$ In contrast, although the clinical experience with naloxone in reversing valproic acidrelated CNS or respiratory depression is too limited to allow for in depth analysis, one review of the literature has suggested that standard-dose naloxone has utility in mild to moderate cases of CNS depression and massive valproic acid overdoses may require larger naloxone doses, or, alternatively, naloxone may simply be ineffective in such a situation. ${ }^{[3]}$

Hossein Sanaei-Zadeh

Medical School, Shiraz University of Medical Sciences, Shiraz, Iran

Correpondence:

Assoc. Prof. Hossein Sanaei-Zadeh, MD, Medical School, Shiraz University of Medical Sciences, Emergency Room/ Division of Medical Toxicology, Hazrat Ali-Asghar (p) Hospital, Meshkinfam

Street, 7143918796 Shiraz, Iran.

E-mail: h-sanaiezadeh@tums.ac.ir

\section{References}

1. Nasa P, Sehrawat D, Kansal S, Chawla R. Effectiveness of hemodialysis in 
a case of severe valproate overdose. Indian J Crit Care Med 2011;15:120-2.

2. Doyon S. Anticonvulsants. In: Nelson LS, Lewin NA, Howland MA,

Hoffman RS, Goldfrank LR, Flomenbaum NE, editors. Goldfrank's Toxicologic Emergencies. ${ }^{\text {th }}$ ed. New York, NY: McGraw-Hill; 2011. p. 698-710.

3. Roberge RJ, Francis EH $3^{\text {rd }}$. Use of naloxone in valproic acid overdose: case report and review. J Emerg Med 2002;22:67-70.

\begin{tabular}{|l|l|}
\hline \multicolumn{2}{|c|}{ Access this article online } \\
\hline Quick Response Code: & Website: \\
\hline & www.ijccm.org \\
\hline
\end{tabular}

